\title{
Top Management Team Characteristics and Return on Assets: Case from the Russian Banking Sector
}

\author{
Elena Prosvirkina \\ National Research University Higher School of Economics \\ School of Business Administration, Moscow, RUSSIAN FEDERATION \\ Bert Wolfs \\ SBS Swiss Business School, Zurich, SWITZERLAND
}

Received 23 May 2019 • Revised 8 July 2019 • Accepted 11 July 2019

\begin{abstract}
Background: According to the upper echelon theory top management team (TMT) characteristics influence on organizational outcomes of a company. Though this topic has been studied in different countries, it is not well researched in Russia, especially for some industries, including banking sector. The main purpose of the research is to study TMT in the Russian banking sector and its influence on return on assets (ROA), one of the metrics of bank's performance.

Methods: Data about top management team characteristics is collected for 178 banks (32\% of banks, operated in Russia). The data includes age, gender, citizenship, education, functional expertise, and work experience of TMT. In addition, data for ROA calculation (net income and total assets) was taken from financial reports of banks. Regression analysis between TMT characteristics and ROA was conducted in SPSS software.

Results: The research found out the portrait of a top manager in Russia. Average age of TMT members equals 46.67 years with the youngest CEO of 29 and oldest CEO of 65 years. Russian banking sector is mostly a male environment (in $77.5 \%$ cases men take the CEO role), however, in majority of banks there is at least one woman. Majority of top managers is Russian citizens (only in $6.7 \%$ of banks CEOs are foreign nationals). And finally, all top managers have higher education and usually their degrees are in Economics, Engineering, and Law. Regression analysis demonstrated that three TMT characteristics influence ROA: percentage of TMT members with scientific degree (with positive effect), gender heterogeneity and CEO duality (with negative effect).

Conclusions: For reaching higher ROA, Board of Directors (BoD) of banks in Russia should appoint more top managers with scientific degree and avoid CEO duality and high gender heterogeneity in TMT.
\end{abstract}

Keywords: top management team, return on assets, banking sector, Russia.

\section{Introduction}

Top managers are studied by many scholars and considered from different perspectives. Researchers investigate individual characteristics, perceptions, and values of top managers in psychology. Behavioral and social scientists study TMT as a group. Scholars from management and economic field pay attention to TMT leadership skills, competencies, team diversity and its influence on a company (expenses, innovation, organizational climate, corporate

(C) Authors. Terms and conditions of Creative Commons Attribution 4.0 International (CC BY 4.0) apply. Correspondence: Elena Prosvirkina, National Research University Higher School of Economics, School of Business Administration, Moscow, RUSSIAN FEDERATION. E-mail: e.prosvirkina@mail.ru. 
values, financial performance, etc.). In 1980 s studies related to TMT were combined in the upper echelons theory, which concentrated on research of basic demographic characteristics, such as age, gender, race, and nationality (Hambrick \& Mason, 1984). Following the development of organizational demography theory, scholars began to study more demographic TMT characteristics, including tenure within the company, previous experience and qualifications. Later heterogeneity (or TMT diversity) became one of the main topics in upper echelons theory.

Nowadays, scholars consider not only TMT characteristics and diversity, but also its influence on organizational outcomes, including finical indicators. This topic is well researched in the USA and Europe. In Russia few researchers considered this topic, but none of them analyzed correlation between TMT characteristics and financial performance of banks. Therefore, the current research is devoted to study TMT characteristics of banks in Russia and investigate if it effect return on assets.

\section{Literature review}

\subsection{Russian banking sector and top managers of banks}

Per Central Bank of Russia (CBR), there are 538 credit institutions licensed to conduct banking operations on the Russian market in 2018. Although the number of credit institutions has been decreasing for the last several years, there are still as many banks in Russia as in the USA, Germany, Austria, and France respectively. Concentration of capital in the Russian banking sector is high.

It is also interesting that Russia is one of the countries with hundreds of banks, but a low real level of competition as in Macedonia, Slovakia, Oman, and Greece. The main reason of the low level of competition is the power of state-controlled banks in Russia, which directly or indirectly controlled by the Bank of Russia or the Russian Federation. Though the number of statecontrolled banks is low (only $5 \%$ of the total number of banks), they own more than a half of total assets of the Russian banking sector (Banking Supervision Report, 2018). Per the Center of Economic Research of the Moscow Financial and Industrial Academy, there are only three big national economies, where state-controlled banks continue to play the main role in the banking sector: China, India, and Russia. Most credit institutions in Russia are local, and only 27\% of them are foreign. In other developing countries, this indicator is higher, for example in East Europe around $70 \%$ of banks are controlled by foreign capital, in Latin America - 40\%.

Currently, the structure of the Russian banking sector's total assets is the following: state-controlled banks (58.6\% of the banking sector's total assets), large private banks (29.8\%), foreign-controlled banks (8.8\%), and small and medium-sized banks based in the Moscow Region as well as in other regions (2.8\%).

In the banking sector in Russia the day-to-day operation of banks is managed by members of the executive board. Executive board members are main decision-makers in bank's operations in Russia and therefore in the current research TMT of Russian banks is considered as a team of executive board members. Executive directors of banks in Russia are employed full-time and are responsible for their area of day-to-day functional or operational business. They attend the executive board meetings and report directly to CEO. Executive directors in banks in Russia set the direction, mission and policies for the business.

As the purpose of the current research is to analyses the influence of TMT characteristics on ROA of banks in the Russian banking sector, it is necessary to determine what TMT characteristics to consider. 


\subsection{TMT characteristics}

Upper echelons theory appeared in 1980s (Hambrick \& Mason, 1984) and since then many studies began to investigate TMT characteristics and its influence on firm performance in different countries. For the research purpose all publications devoted to the TMT characteristics were found in the Elsevier's Scopus database. The search words included "top management", "TMT", "team", "CEO", "Chief Executive Officer", "CFO", "Chief Financial Officer", and "characteristics". 262 articles were selected for the abstract analysis, and finally it appeared that only 98 publications ( 71 articles, 20 conference proceedings, 4 book chapters, and 3 reviews) are relevant to the topic.

Literature review shows that most publications are prepared by the USA, European, and Chinese researchers. No research on the TMT characteristics was found out in Russia. Details on publications by geographic regions are presented in the below table.

Table 1. Number of publications devoted to the TMT characteristics by country

\begin{tabular}{|c|c|c|}
\hline Region & $\begin{array}{c}\text { Total Number of } \\
\text { Publications }\end{array}$ & Number of Publications by Country \\
\hline North America & 40 & 36-USA, 4-Canada \\
\hline Asia & 39 & $\begin{array}{r}\text { 21-China, 4-Taiwan, 4-Tunisia, 2-Malasiya, 2-Singapore, 2-South } \\
\text { Korea, 1-Hong Kong, 1-Qatar, 1-Thailand, 1-Yemen }\end{array}$ \\
\hline Europe & 31 & $\begin{array}{c}\text { 5-UK, 4-Germay, 4-Italy, 4-Spain, 3-Belgium, 3-Norway, 2-France, 1- } \\
\text { Finland, 1-Nethelands, 1-Portugal, 1-Poland, 1-Romania, 1-Turkey }\end{array}$ \\
\hline Oceania & 7 & 5-Australia, 2-New Zealand \\
\hline
\end{tabular}

Source: Developed by the authors

The first researchers of the executive teams considered basic demographic characteristics, such as age, gender, race, and nationality (Barnard, 1938). Following the development of organizational demography theory (Pfeffer, 1983) scholars began to study more demographic characteristics, including tenure within the company, previous experience and qualifications (Korac-Kakabadse et al., 2001). Functional tracks and other career experiences of each TMT are also important characteristics (Hambrick \& Mason, 1984). Rresearchers analyse functional background (Yoon et al., 2016; Díaz-Fernández et al., 2014), international experience (Bany-Ariffin et al., 2014; Herrmann \& Datta, 2005), executive experience (Bjornal et al., 2016; Yang et al., 2011) or industry experience (Ahrens et al., 2015; Knockaert, 2015).

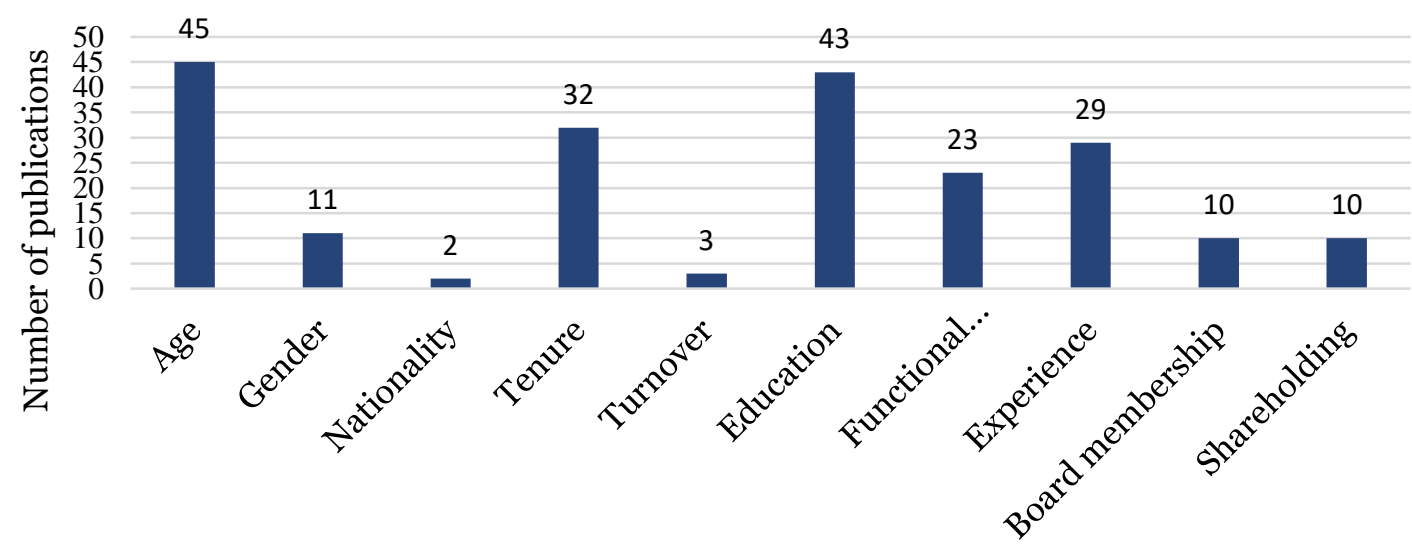

TMT characteristics

Figure 1. Results of frequency analysis of the TMT demographic characteristics 
E. Prosvirkina \& B. Wolfs - Top Management Team Characteristics and Return on Assets: Case from...

For the deeper understanding of what the TMT characteristics are considered more often, all 98 selected publications were analyzed and frequency analysis of appearance of each TMT characteristic was conducted. Results of the analysis are presented in the previous figure.

The latest publications are usually devoted not to TMT characteristics itself, but to TMT heterogeneity (or diversity). It can be determined as the differences in TMT members with respect to their demographics (Oduor \& Kilika, 2018), for example, diversity in TMT tenure (Jaw, Lin, 2009). Other researchers consider educational diversity (Yoon et al., 2016; Zahra \& Wiklund, 2010), functional diversity (Bjornali at al.; 2011; Buyl et al., 2011), and gender diversity (Wen et al., 2015; Yang \& Wang, 2014).

\subsection{ROA and TMT characteristics}

There are many approaches of estimating firm performance depending on the level of analysis, including human, operational, and financial levels (Ketkar \& Sett, 2009). Financial outcomes are considered more frequently than operational or human, because usually financial indicators are objective and data for its calculation is publicly available in the financial reports of companies. Therefore, in this study only financial performance is taken into consideration.

In the upper echelon research devoted to the analysis of TMT characteristics' influence on organizational outcomes, authors consider both market-based and accounting measures to assess financial performance. Return on assets is the most frequently used indicator among accounting-based measures. It was taken as a main performance indicator in several TMT studies (Díaz-Fernández et al., 2014; Marcel, 2009; Goll et al., 2008; Ben Cheikh \& Zarai, 2008, etc.). These studies generate diverse results by founding out positive, negative or no relationship between the TMT characteristics and ROA. Details of the empirical findings are presented in the below table.

Table 2. Research examples of relationship between TMT characteristics and ROA

\begin{tabular}{|c|c|c|c|}
\hline Correlation & Authors & Industry/Sector & TMT Characteristics \\
\hline No & $\begin{array}{l}\text { Díaz-Fernández et } \\
\text { al., } 2014\end{array}$ & Spanish large companies & TMT functional diversity \\
\hline \multirow{4}{*}{ Negative } & Peni, 2014 & $\begin{array}{l}\text { Firms from a variety of } \\
\text { industries }\end{array}$ & CEO holding multiple board seats \\
\hline & $\begin{array}{l}\text { Díaz-Fernández et } \\
\text { al., } 2014\end{array}$ & Spanish large companies & TMT's education-level diversity \\
\hline & Marcel, 2009 & 153 firms in five industries & CEO/COO duality \\
\hline & Goll et al., 2008 & Major US airlines & $\begin{array}{l}\text { TMT age (during the deregulatory } \\
\text { period) }\end{array}$ \\
\hline \multirow{5}{*}{ Positive } & Peni, 2014 & $\begin{array}{c}\text { Firms from a variety of } \\
\text { industries }\end{array}$ & $\begin{array}{c}\text { - Presence of female CEO } \\
\text { - CEO duality } \\
\text { - CEO experience }\end{array}$ \\
\hline & Li \& Zhang, 2014 & Chinese listed firms & $\begin{array}{c}\text { - CEO age } \\
\text { - CEO education level } \\
\text { - CEO generated internally }\end{array}$ \\
\hline & Buyl et al., 2011 & Dutch and Belgian IT firms & TMT functional diversity \\
\hline & Goll et al., 2008 & Major US airlines & $\begin{array}{c}\text { - TMT education level (under } \\
\text { regulation) } \\
\text { - TMT tenure and functional diversity } \\
\text { (during the deregulatory period) }\end{array}$ \\
\hline & $\begin{array}{l}\text { Ben Cheikh \& } \\
\text { Zarai, } 2008\end{array}$ & Tunisian companies & CEO power \\
\hline
\end{tabular}

Source: Developed by the authors 
The above data demonstrates that for different industries and different countries results are diverse. For example, TMT functional diversity has no influence on ROA in Spanish large companies but has positive effect in Dutch and Belgian IT firms as well as in major US airlines during the deregulatory period. This means that local and industry specifics can determine what TMT characteristics has influence on ROA in various cases. As there is no evidence from Russia, the current research investigates if TMT characteristics influence ROA of banks on the Russian market. Methodology of the research is described in the next section.

\section{Research design and methodology}

\subsection{Research design}

This research adopts mixed research techniques and quantitative approach to data sources and analysis. Such approach helps to provide insightful and objective knowledge for the study and answer the below research questions:

1. What are the main TMT characteristics in the Russian banking sector?

2. Is there a correlation between TMT characteristics and ROA?

3. What TMT characteristics have positive and negative effect on ROA?

Literature review found out the most frequently used TMT characteristics, which are used for analysis of TMT diversity. All of them are investigated in the research, including diversity of TMT demographic characteristics, work experience, and education. The research investigates the linkage between TMT characteristics and ROA. The below theoretical model addresses the main purpose of the research (Figure 2).

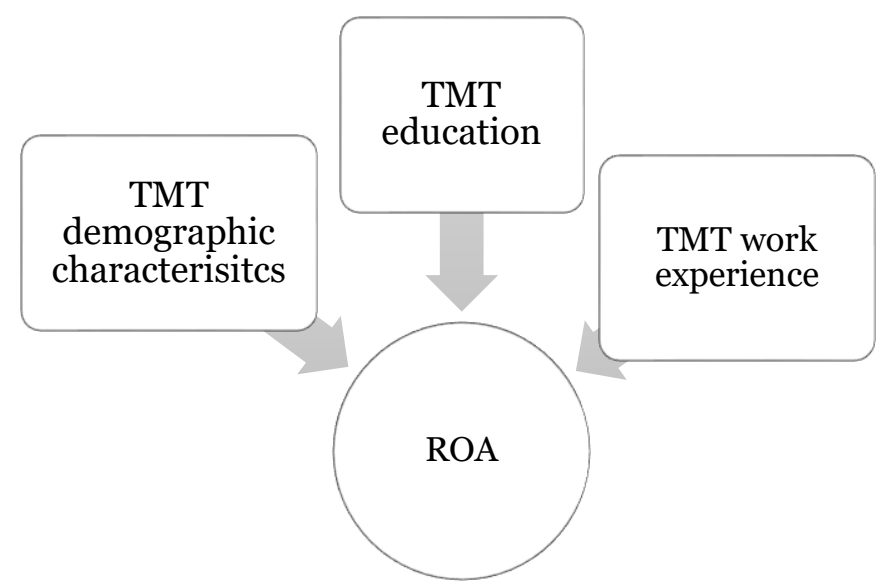

Figure 2. Theoretical Model of the Research

Source: Developed by the authors

\subsection{Data collection}

The research includes different types of secondary data. Firstly, data about TMT members was collected from websites of banks. Data about demographic characteristics, work experience, and education is available. According to the Russian legislation banks must publish these data for top managers. Websites for 178 banks were studied and data about TMT was summarized in Excel for further coding. For majority of banks this data was published in Russian, 
E. Prosvirkina \& B. Wolfs - Top Management Team Characteristics and Return on Assets: Case from...

therefore it then further has been translated in English for the coding purposes. Summary of data collected about TMT characteristics' is presented in the Table 3.

Table 3. Data collected about TMT members' characteristics

\begin{tabular}{|c|c|c|}
\hline Type of Data & Variables & Source of Data \\
\hline $\begin{array}{l}\text { Demographic } \\
\text { characteristics }\end{array}$ & $\begin{array}{ll} & \text { Name } \\
\text { - } & \text { Gender } \\
\text { - } & \text { Age } \\
\text { - } & \text { Nationality } \\
\end{array}$ & \multirow{3}{*}{$\begin{array}{l}\text { Websites of banks } \\
\text { (usually in the } \\
\text { "Corporate } \\
\text { Governance" } \\
\text { section) }\end{array}$} \\
\hline Work Experience & $\begin{array}{ll} & \text { Position } \\
\text { - } & \text { Core function } \\
\text { - } & \text { Job history } \\
\text { - } & \text { International experience }\end{array}$ & \\
\hline Education & $\begin{array}{ll} & \text { University } \\
\text { - } & \text { Major } \\
\text { - } & \text { Additional education } \\
\text { - } & \text { Scientific degree } \\
\text { - } & \text { Field } \\
\end{array}$ & \\
\hline
\end{tabular}

Source: Developed by the authors

Secondly, data about net income and total assets was collected from financial statement of each bank. This data is necessary for ROA calculation, which is calculated based on the following formula:

$$
\text { ROA }=\frac{\text { Net Income }}{\text { Total assets }}
$$

Return on assets gives an idea as to how efficient management is at using its assets to generate earnings. It helps to identify how profitable a company is relative to its total assets (Pena \& Villasarelo, 2010).

\subsection{Sample}

The size of the banks in this survey is mostly average. 50.6\% of the sample have less than 500 employees. Only 3.4\% have more than 10000 employees. According to the EU definition from the Centre of Strategy and Evaluation Services ${ }^{1}$, an institution that has below 250 employees, is defined as a small and medium enterprises. In this study, 51 banks (28.7\% of the sample) are therefore small and medium sized organizations. The majority are big banks.

The review of the banking sector in Russia has shown that most banks are private, and only few are government controlled. In this survey $15.2 \%$ are government-controlled banks and $84.8 \%$ of the sample are private banks. Most banks are local (74.7\%), only $25.3 \%$ are international banks. More than $80 \%$ of banks in the sample are universal, which means that they provide different type of financial services for both private and corporate clients. Three other categories are represented by 5-6\% of banks. This represents well the whole Russian banking sector, where there is a small number of corporate, retail or investment banks.

The concentration of capital refers to the shareholder structure of a bank. If there is one shareholder, who controls key decision-making processes then the concentration of capital is high. If there are many minority shareholders, then that concentration is low. More than sixty

5 Centre of Strategy and Evaluation Services: http://www.cses.co.uk/. 
percent of banks have a high concentration of capital and $28.7 \%$ have a low capital concentration. The rest of the banks have several shareholders, who control main management decisions.

\subsection{Data analysis}

The current research is quantitative and statistical analysis was applied for analysis of the coded data. For some variables coding was not required (name of TMT member, age), but other variables were coded for further analysis in SPSS. To evaluate TMT heterogeneity, coefficient of variance $(\mathrm{CV})$ was calculated. Formula of $\mathrm{CV}$ is outlined below.

$\boldsymbol{C V}=(\boldsymbol{S D} / \boldsymbol{\mu}){ }^{*} \mathbf{1 O o}$, where SD - standard deviation, $\mu$ - mean.

$\boldsymbol{S D}=\frac{\sum_{i=1}^{N}\left|x_{i}-\mu\right|^{2}}{N}, \mathrm{~N}$ - number of values.

- $<17 \%$ - very homogeneous;

- $17-33 \% \%$ - homogeneous;

- $35-40 \% \%$ - slightly homogeneous;

- 40-60\%\% - slightly heterogeneous;

- >60\% - heterogeneous.

Finally, regression analysis was applied to investigate if TMT characteristics and TMT heterogeneity influence ROA of banks in Russia.

4. Research findings

Variance coefficient was calculated for all TMT characteristics of each bank. The research found out minimum, maximum, average, and standard deviation of variance coefficient for all top management team characteristics. The results are presented in the Table 4.

Table 4. Variance coefficient for TMT characteristics

\begin{tabular}{|c|c|c|c|c|}
\hline TMT Characteristics & Minimum & Maximum & Average & Standard Deviation \\
\hline Gender & 0 & 0.47 & 0.3193 & 0.12531 \\
\hline $\begin{array}{c}\text { Citizenship } \\
\text { experience }\end{array}$ & 0 & 0.99 & 0.0843 & 0.21111 \\
\hline Education & 0 & 0.76 & 0.0124 & 0.05687 \\
\hline Current functional expertise & 0 & 1.11 & 0.6113 & 0.25746 \\
\hline $\begin{array}{c}\text { Work experience in the banking } \\
\text { sector }\end{array}$ & 0 & 0.43 & 0.2198 & 0.18367 \\
\hline $\begin{array}{c}\text { Functional work experience } \\
\text { International work experience }\end{array}$ & 0 & 1.15 & 0.6392 & 0.21162 \\
\hline $\begin{array}{c}\text { Membership in the Board of } \\
\text { Directors }\end{array}$ & 0 & 0.43 & 0.0435 & 0.11173 \\
\hline
\end{tabular}

Source: Developed by the authors

The calculated meanings of average, maximum, and standard deviation for variance coefficient for different top management characteristics show that TMT in the Russian banking sector are heterogeneous in terms of their current functional expertise, functional work experience, and education background. This finding can be simply explained by the fact that top management teams in banks usually consist of heads of functional departments, who should have 
E. Prosvirkina \& B. Wolfs - Top Management Team Characteristics and Return on Assets: Case from...

education background and work experience related to their function. If we consider other top management characteristics, TMT are homogeneous. In average, top management team in Russia consist majority of Russian men with the same duration of their membership in the executive board and usually with the work experience in the Russian banking sector without international working background.

Regression analysis was conducted to study the influence of TMT characteristics on ROA. Three models created in SPSS with stepwise regression are presented below.

Table 5. Regression models summary (ROA)

\begin{tabular}{|c|c|c|c|c|c|c|c|c|c|c|}
\hline \multirow{2}{*}{ Model } & \multirow{2}{*}{$\mathrm{R}$} & \multirow{2}{*}{$\begin{array}{c}\mathrm{R}- \\
\text { squared }\end{array}$} & $\begin{array}{c}\text { Adjusted } \\
\mathrm{R}-\end{array}$ & $\begin{array}{c}\text { Std. } \\
\text { squared } \\
\text { the } \\
\text { Estimate }\end{array}$ & $\begin{array}{c}\mathrm{R} \\
\text { squire } \\
\text { change }\end{array}$ & $\begin{array}{c}\mathrm{F} \\
\text { change }\end{array}$ & df1 & df2 & $\begin{array}{c}\text { Sig. F } \\
\text { change }\end{array}$ & $\begin{array}{c}\text { Wurbin- } \\
\text { Statistic }\end{array}$ \\
\hline 1 & $.188^{\mathrm{a}}$ & .035 & .030 & .09636 & .035 & 6.413 & 1 & 176 & .012 & \\
2 & $.263^{\mathrm{b}}$ & .069 & .059 & .09492 & .034 & 6.394 & 1 & 175 & .012 & \\
3 & $.303^{\mathrm{c}}$ & .092 & .076 & .09404 & .022 & 4.283 & 1 & 174 & .040 & 2.017 \\
\hline
\end{tabular}

(a) Predictors: (Constant) Gender heterogeneity

(b) Predictors: (Constant) Gender heterogeneity, percentage of TMT members with scientific degree

(c) Predictors: (Constant) Gender heterogeneity, percentage of TMT members with scientific degree, CEO duality

Source: Developed by the authors

The analysis shows that the third model has the highest value of R-squared (0.092) and adjusted R-squared (0.076). This means that this model is more suitable for explanation of how TMT characteristics determine ROA. According to this model only three indicators influence ROA: gender heterogeneity, percentage of TMT members with scientific degree, and membership of CEO in BoD. Regression coefficients are outlined in the below table.

Table 6. Regression coefficients for TMT characteristics (ROA)

\begin{tabular}{|c|c|c|c|c|c|c|c|}
\hline \multirow{2}{*}{ Model (3) } & \multicolumn{2}{|c|}{$\begin{array}{l}\text { Unstandardized } \\
\text { coefficients }\end{array}$} & \multirow{2}{*}{$\begin{array}{c}\begin{array}{c}\text { Standardized } \\
\text { coefficients }\end{array} \\
\text { Beta }\end{array}$} & \multirow{2}{*}{$\mathrm{t}$} & \multirow{2}{*}{$\mathrm{P}>\mathrm{t}$} & \multicolumn{2}{|c|}{$\begin{array}{l}\text { [95\% Conf. } \\
\text { Interval] }\end{array}$} \\
\hline & B & $\begin{array}{l}\text { Std. } \\
\text { Err. }\end{array}$ & & & & $\begin{array}{l}\text { Lower } \\
\text { Bound }\end{array}$ & $\begin{array}{l}\text { Upper } \\
\text { Bound }\end{array}$ \\
\hline (Constant) & .092 & .027 & & 3.360 & .001 & .038 & .146 \\
\hline Gender heterogeneity & -.160 & .057 & -.205 & -2.82 & .005 & -.272 & -.048 \\
\hline $\begin{array}{l}\% \text { of TMT members with } \\
\text { scientific degree }\end{array}$ & .002 & .001 & .215 & 2.919 & .004 & .001 & .003 \\
\hline CEO duality & -.023 & .011 & -.154 & -2.07 & .040 & -.045 & -.001 \\
\hline
\end{tabular}

Source: Developed by the authors

According to the above table gender heterogeneity negatively effects bank's ROA on the Russian market (standardized coefficient is minus 0,205). This result shows that in banks with homogenous TMT in terms of gender ROA is higher. As only in 6 banks from the sample (3.4\%) all top managers are women, homogenous TMT mainly refers to the male TMT. This research finding contradicts with other international researches, which state that business organizations 
achieve higher financial performance results in case of higher gender heterogeneity (Wen et al., 2015; Yang \& Wang, 2014).

Percentage of TMT members with scientific degree positively effects ROA (standardized coefficient is 0.215), which means that TMTs with higher number of PhD holders reach higher ROA. This is not necessarily connected with $\mathrm{PhD}$ itself, but with personal qualities of $\mathrm{PhD}$ holders. These individuals are usually goal-oriented, have good critical thinking and analytical skills, which are important in managing a bank.

Another interesting observation is that CEO duality negatively influences ROA of a bank in Russia (standardized coefficient is minus o.154). This negative effect can be explained by several things. Firstly, CEO duality may create conflicts of interest. Secondly, BoD can heavily rely on CEO's opinion, and therefore CEO has too much influence on the board decisions. Thirdly, CEO membership in BoD can limit opportunities of adequate supervision and evaluation of bank's management.

The described line regression model does not include organizational characteristics of banks. As ROA can vary for different types of banks, it is important to take them into consideration. Line regression model has been updated after inclusion of all organizational characteristics of banks (considered in the research). Four models were created with stepwise regression, and the fourth one has the highest value of R-squared (0.113) and adjusted R-squared (o.093). Regression coefficients are outlined in the below table.

Table 7. Regression coefficients for TMT and organizational characteristics (ROA)

\begin{tabular}{|c|c|c|c|c|c|c|c|}
\hline \multirow{2}{*}{ Model (4) } & \multicolumn{2}{|c|}{$\begin{array}{l}\text { Unstandardized } \\
\text { coefficients }\end{array}$} & \multirow{2}{*}{$\begin{array}{c}\begin{array}{c}\text { Standardized } \\
\text { coefficients }\end{array} \\
\text { Beta }\end{array}$} & \multirow{2}{*}{$\mathrm{t}$} & \multirow{2}{*}{$P>t$} & \multicolumn{2}{|c|}{$\begin{array}{l}\text { [95\% Conf. } \\
\text { Interval] }\end{array}$} \\
\hline & B & $\begin{array}{l}\text { Std. } \\
\text { Err. }\end{array}$ & & & & $\begin{array}{l}\text { Lower } \\
\text { Bound }\end{array}$ & $\begin{array}{l}\text { Upper } \\
\text { Bound }\end{array}$ \\
\hline (Constant) & .162 & .044 & & 3.722 & .000 & .076 & .248 \\
\hline Gender heterogeneity & -.152 & .056 & -.194 & -2.68 & .008 & -.263 & -.040 \\
\hline $\begin{array}{c}\% \text { of TMT members with } \\
\text { scientific degree }\end{array}$ & .002 & .001 & .207 & 2.829 & .005 & .001 & .003 \\
\hline Type of Ownership & -.040 & .020 & -.148 & -2.06 & .041 & -.079 & -.002 \\
\hline CEO duality & -.022 & .011 & -.146 & -1.98 & .049 & -.044 & .000 \\
\hline
\end{tabular}

Source: Developed by the authors

Inclusion of organizational characteristics in the regression model showed that type of ownership influences ROA in addition to three identified TMT characteristics. Regression coefficient equals minus 0.148. Type of ownership is a binominal distribution in the current research, where 1 refers to a private bank, and 2 - to a state-owned bank. This means that for private banks ROA is higher than for state-owned banks on the Russian market despite the differences in TMT characteristics.

\section{Conclusions}

Top management team in the Russian banking sector is mostly homogeneous. TMTs are homogeneous in terms of their age, gender, nationality, and previous industry work experience. Top managers in banks are usually Russian men at the age of 40-50 years with previous work experience only in the banking sector. TMTs have diverse educational background (Economics, Math's, Physics, Law or another field) and functional expertise (general management, finance, sales, human resource management, etc.). 
The research also found out that in Russia CEO duality and gender heterogeneity have a negative effect on ROA, while higher percentage of top managers with scientific degree is associated with positive effect on ROA. Other TMT characteristics have no impact. This means that for reaching higher ROA, Board of Directors of banks in Russia should appoint more top managers with scientific degree and avoid CEO duality and high gender heterogeneity in TMT.

In considering the conclusions of the study, limitations have been identified concerning the research only in the banking sector of Russia, as it might not be fully representative. This limitation has affected the results of the study, as a broader sample could have brought further expertise. Even though this limitation may apply, the paper is still valid. The study can be used to justify further studies as well as a way of adding to existing knowledge.

\section{Acknowledgements}

This research did not receive any specific grant from funding agencies in the public commercial, or not-for-profit sectors.

The authors declare no competing interests.

\section{References}

Ahrens, J., Landmann, A., \& Woywode, M. (2015). Gender preferences in the CEO successions of family firms: Family characteristics and human capital of the successor. Journal of Family Business Strategy, 6(2), 86-103. https://doi.org/10.1016/j.jfbs.2015.02.002

Banking Supervision Report (2018). Moscow: Bank of Russia, 1-100.

Bany-Ariffin, A. N., McGowan, C. B., Tunde, M. B., \& Shahnaz, A. S. (2014). Top management characteristics and firm's international diversification activities: Evidence from a developing nation. Pertanika Journal of Social Science and Humanities, 22, 39-54.

Barnard, C. I. (1938). The functions of the executives. Cambridge, MA: Harvard University Press.

Ben Cheikh, S., \& Zarai, M. A. (2008). Impact of managerial power and the personal characteristics of CEO on the performance: Case of the Tunisian companies. Corporate Ownership and Control, 5(3 E SPEC. ISSUE), 452-462.

Bjørnåli, E. S., Erikson, T., \& Knockaert, M. (2011). The impact of top management team characteristics and board strategic involvement on team effectiveness in high-tech start-UPS. Paper presented at the Academy of Management 2011 Annual Meeting - West Meets East: Enlightening. Balancing. Transcending, AOM 2011. https://doi.org/10.5464.AMBPP.2011.166

Bjornali, E. S., Knockaert, M., \& Erikson, T. (2016). The impact of top management team characteristics and board service involvement on team effectiveness in high-tech start-ups. Long Range Planning, 49(4), 447-463. https://doi.org/10.1016/j.lrp.2015.12.014

Buyl, T., Boone, C., Hendriks, W., \& Matthyssens, P. (2011). Top management team functional diversity and firm performance: The moderating role of CEO characteristics. Journal of Management Studies, 48(1), 151-177. https://doi.org/10.1111/j.1467-6486.2010.00932

Díaz-Fernández, M. C., González-Rodríguez, M. R., \& Pawlak, M. (2014). Top management demographic characteristics and company performance. Industrial Management and Data Systems, 114(3), 365-386. https://doi.org/10.1108/IMDS-04-2013-0210 
Goll, I., Brown Johnson, N., \& Rasheed, A. A. (2008). Top management team demographic characteristics, business strategy, and firm performance in the US airline industry: The role of managerial discretion. Management Decision, 46(2), 201-222.

https://doi.org/10.1108/00251740810854122

Hambrick, D. C. \& Mason, P. (1984). Upper echelons: the organization as a reflection of its top managers. Academy of Management Review, 9(2), 193-206.

Herrmann, P., \& Datta, D. K. (2005). Relationships between top management team characteristics and international diversification: An empirical investigation. British Journal of Management, 16(1), 69-78. https://doi.org/10.1111/j.1467-8551.2005.00429

Jaw, Y., \& Lin, W. (2009). Corporate elite characteristics and firm's internationalization: CEO-level and TMT-level roles. International Journal of Human Resource Management, 2O(1), 220-233. https://doi.org/10.1080/09585190802528797

Knockaert, M., Bjornali, E. S., \& Erikson, T. (2015). Joining forces: Top management team and board chair characteristics as antecedents of board service involvement. Journal of Business Venturing, 3o(3), 420-435. https://doi.org/10.1016/j.jbusvent.2014.05.001

Korac-Kakabadse, N., Kakabadse, A. K., \& Kouzmin, A. (2001). Board governance and company performance: any correlations? Corporate Governance, 1(1), 24-30.

Marcel, J. J. (2009). Why top management team characteristics matter when employing a chief operating officer: A strategic contingency perspective. Strategic Management Journal, 30(6), 647-658. https://doi.org/10.1002/smj.763

Oduor, B. A., \& Kilika, J. M. (2018). TMT Diversity, Decision Quality and Service Sector Firm Performance: A Research Agenda. Journal of Management and Strategy, 9(2), 34-45.

Pfeffer, J. (1983). Organizational demography. Research in Organizational Behaviour, 5, 299-357.

Wen, M., Gao, J., Liang, L., \& Lu, Q. (2015). Study on the moderating effect of top management team characteristics on the relationship between equity incentive and internal control quality. Paper presented at the 2015 12th International Conference on Service Systems and Service Management, ICSSSM 2015. https://doi.org/10.1109/ICSSSM.2015.7170296

Yang, Q., Zimmerman, M., \& Jiang, C. (2011). An empirical study of the impact of CEO characteristics on new firms' time to IPO. Journal of Small Business Management, 49(2), 163-184. https://doi.org/10.1111/j.1540-627X.2011.00320

Yang, L., \& Wang, D. (2014). The impacts of top management team characteristics on entrepreneurial strategic orientation: The moderating effects of industrial environment and corporate ownership. Management Decision, 52(2), 378-409. https://doi.org/10.1108/MD-03-2013$\underline{0140}$

Yoon, W., Kim, S. J., \& Song, J. (2016). Top management team characteristics and organizational creativity. Review of Managerial Science, 10(4), 757-779. https://doi.org/10.1007/s11846-015-0175-7

Zahra, S. A., \& Wiklund, J. (2010). The effect of top management team characteristics on product innovation among new ventures: The moderating role of behavioral integration. Paper presented at the Academy of Management 2010 Annual Meeting - Dare to Care: Passion and Compassion in Management Practice and Research, AOM 2010. 
E. Prosvirkina \& B. Wolfs - Top Management Team Characteristics and Return on Assets: Case from... 